(C) 1988 ISIJ

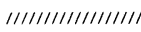

論 文

|IIIIIIIIIIIIIIIII
Ti と炭素鋼の接合性と界面反応

$$
\text { 小溝 } \text { 裕一 }^{*} \cdot \text { 村山順一郎 }{ }^{* 2} \cdot \text { 大谷 泰夫* }
$$

\title{
Bonding Characteristics and Interface Reactions in Cladding of Titanium to Carbon Steel
}

Yu-ichi Komizo, Junichiro Murayama and Hiroo Ohtani

\begin{abstract}
Synopsis :
A study was done in order to get the preferable interface strength in a cladding of titanium to carbon steel from the view point of diffusion of metallic elements and the formation of intermetallic compounds. The formation of titanium carbide lowered the interfacial strength in a direct cladding of titanium to steel.

In the case of cladding of titanium to steel with an insert metal of nickel, the intermetallic compounds of $\mathrm{Ni}_{3} \mathrm{Ti}, \mathrm{NiTi}$ and $\mathrm{NiTi}_{2}$ were observed at the bonding interface of $\mathrm{Ni} / \mathrm{Ti}$. The voids which were thought to be induced by Kirkendal effect were also observed at $\mathrm{Ni} / \mathrm{Ni}_{3} \mathrm{Ti}$ layer. Holding a long time at elevated temperature lowered the interfacial strength due to the formation of wide intermetallic compounds which grew according to the parabolic law.

In the case of cladding of titanium to steel with the insert metal of pure iron, the intermetallic compounds of $\mathrm{Fe}_{2} \mathrm{Ti}$ and $\mathrm{FeTi}$ were observed at the bonding interface of $\mathrm{Fe} / \mathrm{Ti}$. However, the growth rate of these intermetallic compounds was quite small compared with that in the case of $\mathrm{Ni} / \mathrm{Ti}$ system. From the analysis of $\mathrm{Ti} / \mathrm{Fe} /$ carbon steel joint heated up to an elevated temperature after rolling, the $\mathrm{TiC}$ as well as $\mathrm{Fe}-\mathrm{Ti}$ intermetallic compounds were formed along the bonding interface because the carbon atoms diffuse from the carbon steel through the insert metal of $\mathrm{Fe}$. Therefore, the carbon steel $/ \mathrm{Ni} / \mathrm{Fe} / \mathrm{titanium}$ system was useful to get the preferable interface strength in the cladding of titanium to carbon steel.
\end{abstract}

Key words : hot rolled product ; composite material; titanium base alloy ; diffusion ; interface ; intermetallic compound; diffusion bonding ; cladding.

\section{1. 緒言}

近年, チタン（Ti）または $\mathrm{Ti}$ 合金の有する耐食性に 着目し，炭素鋼や低合金鋼の母材に、これら Ti または

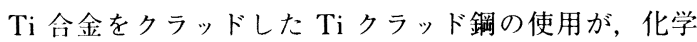
装置類を中心として増加する傾向をみせている.

鉄系金属を母材とした Ti クラッド材の製造法とし て, 従来知られているのは, 爆着室内において爆薬を爆 発させ，その衝撃圧により対向配置した母材と合せ材と を接合する爆着法である ${ }^{1) 2}$. これは活性金属である $\mathrm{Ti}$ が多くの金属元素と金属間化合物を形成しやすいうえ， 形成された金属間化合物のほとんどは脆くて, 加工性が 著しく劣るものであることから，接合界面における元素 搪散により母材と合せ材とを接合させるようなクラッド 製造法が適用しにくいことによる．しかし，爆着法では
薄板材の製造や大面積のクラッディングが困難であると いうように，製品寸法に制限があるうえ，大量生産方式 の採用が難しいという問題点がある.

そこで，本報では，ステンレスクラッド鋼の製造など に採用されている熱間圧延法による $\mathrm{Ti}$ クラッド鋼製造 を目的に，接合界面の元素拡散挙動と金属間化合物層の 生成に着目して, Ti と炭素鋼の接合性を調査した。

\section{2. 実 験 方 法}

熱間压延材の接合強度を調べるため, Fig. 1 に示す ように箱型の炭素鋼 (SM 50) と工業用純 Ti 板をサン ドイッチ状に組み立てた，組立てに際しては，まず三辺 をGTA 溶接（ティグ溶接）した後, 第四辺に脱気管を 取り付け，ロータリーポンプにて $10^{-1} \sim 10^{-2}$ torr に 脱気した。ここで, 組立て後の厚さは $90 \mathrm{~mm}$ とし, 純

昭和 61 年 10 月本会講演大会にて発表 昭和 62 年 9 月 30 日受付 (Received Sep. 30, 1987)

* 住友金属工業(株)鉄鋼技術研究所工博 (Iron \& Steel Research Laboratories, Sumitomo Metal Industries, Ltd., 1-3 Nishinagasuhondori Amagasaki 660)

*2 住友金属工業(株)鉄鋼技術研究所（現：住金テクノリサーチ(株))（Iron \& Steel Research Laboratories, Sumitomo Metal Industries, Ltd., Now SMI Techno-Research, Ltd.) 


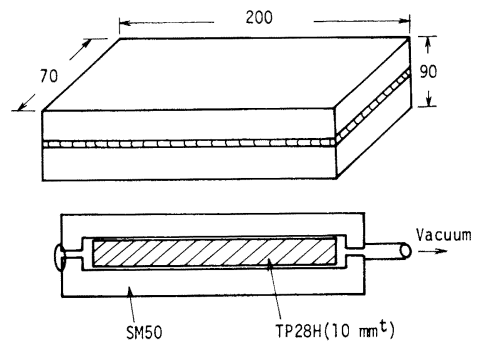

Fig. 1. Test block before hot-rolling.

$\mathrm{Ti}$ 板の厚さを $10 \mathrm{~mm}$ とした．接合面の表面粗さが重要 と考えられたので，炭素鋼内表面ならびに $\mathrm{Ti}$ 板とも機 械加工にて約 $2 \mu \mathrm{m}$ の表面粗さに仕上げた. 炭素鋼と Ti 板の化学成分を Table 1 に示す.

サンドイッチ状に組み立てるとき，一部のものはイン サート金属を介して組み立てた。インサート金属として は市販の純ニッケル $(\mathrm{Ni})$ 䇴（厚さ $100 \mu \mathrm{m} ）$ および電解 鉄を真空溶解して製造した純鉄（厚さ $1 \mathrm{~mm}$ )を用いた. 純鉄 $(\mathrm{Fe})$ には $0.008 \mathrm{wt} \%$ の炭素が含まれていた。組 み立てた素材を熱間圧延し，36 mm 厚のクラッド鋼板 を得た（以後，圧延材と呼ぶ）。熱間圧延後のクラッド 鋼板より板厚方向に平行部 $12 \mathrm{~mm}$, 直径 $6 \mathrm{~mm}$ の丸棒引 張試験片を採取し，接合強度を測定した。また，一部の ものは熱間加工等を想定して，圧延材を所定の温度に再 加熱して接合強度を測定した.

また, 直径 $12 \mathrm{~mm}$, 長さ $8 \mathrm{~mm}$ の試料を $5 \times 10^{-2} \mathrm{~Pa}$ の真空チャンバー内で $19.8 \mathrm{MPa}$ の初期荷重のもとで高
周波加熱することにより，接合実験を行つた（以後，接 合材と呼ぶ). 接合した試験片の断面を光学顕微鏡, 走 査型電子顕微鏡で観察した，元素の拡散挙動は，波長分 散型 EPMA による線分析およびエネルギー分散型 EPMA による各点の組成分析により求めた。ささらに, X線回折により引張試験片破面上の化合物を同定した. このとき，一次照射 $\mathrm{X}$ 線は $\mathrm{CoK}_{\alpha}$ を用いた。

\section{3. 実 験 結 果}

\section{$3 \cdot 1$ インサート金属を用いない場合の接合性}

インサート材を用いないで $1123 \mathrm{~K}$ で $921.6 \mathrm{ks}$ 保持 した接合材の炭素鋼/Ti 界面の状況を Photo. 1 に示す. 界面には $\mathrm{TiC}$ が観察された。

$1123 \mathrm{~K}$ に $5.4 \mathrm{ks}$ 保持後圧延した供試材の板厚方向か ら採取した丸棒試験片により求めた界面強度は 35～371 $\mathrm{MPa}$ と大きくばらついていた。ここで，試験片は接合 界面で破断していた。 Ti 側破面のX線回折結果を Fig. 2 に示す。破面上には $\mathrm{TiC}$ が観察され，これが高い接 合強度の得られない理由とする従来の結果 ${ }^{3) 4)}$ と一致し ている.

\section{$3 \cdot 2 \mathrm{Ni}$ をインサート金属とする場合の接合性}

$\mathrm{Ni}$ をインサート材として，1123 K に加熱した圧延材 の接合強度と压延前の加熱保持時間の関係を Fig. 3 に 示す．保持時間が短いときは安定して高い接合強度が得 られるが，長時間保持すると接合強度が低下した。

$1123 \mathrm{~K}$ での接合材 (57.6 ks 保持) の $\mathrm{Ti} / \mathrm{Ni}$ 界面の SEM 観察結果を Photo. 2 に示す。界面には濃淡の異 なる三層の金属間化合物が観察され，その $\mathrm{Ni}$ 側にはボ

Table 1. Chemical compositions of materials used (wt\%).

\begin{tabular}{|c|c|c|c|c|c|c|c|c|c|}
\hline & $\mathrm{C}$ & $\mathrm{Si}$ & $\mathrm{Mn}$ & $\mathrm{P}$ & $\mathrm{S}$ & $\mathrm{Ti}$ & $\mathrm{Fe}$ & $\mathrm{O}$ & $\mathrm{N}$ \\
\hline Base metal & 0.12 & 0.33 & 1.08 & 0.017 & 0.004 & - & Bal. & - & - \\
\hline Cladding metal & - & - & - & - & - & Bal. & 0.061 & 0.138 & 0.009 \\
\hline
\end{tabular}

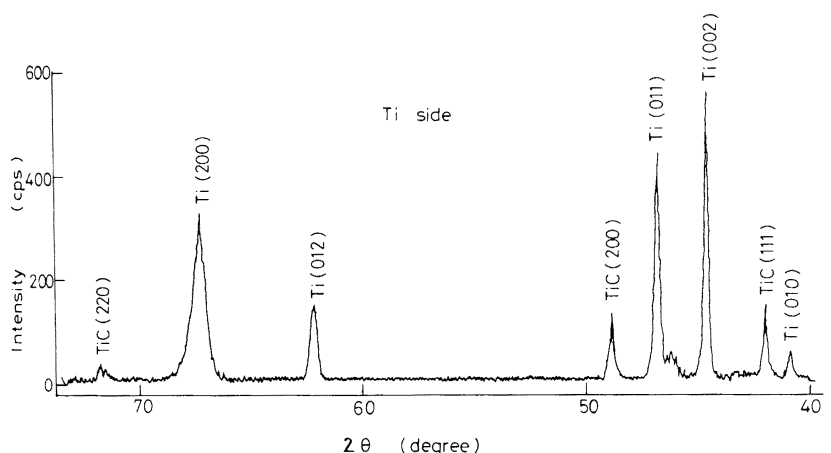

Fig. 2. X-ray diffraction pattern from fractured surface of carbon steel/ $\mathrm{Ti}$ joint without insert metal rolled at $1123 \mathrm{~K}$. 

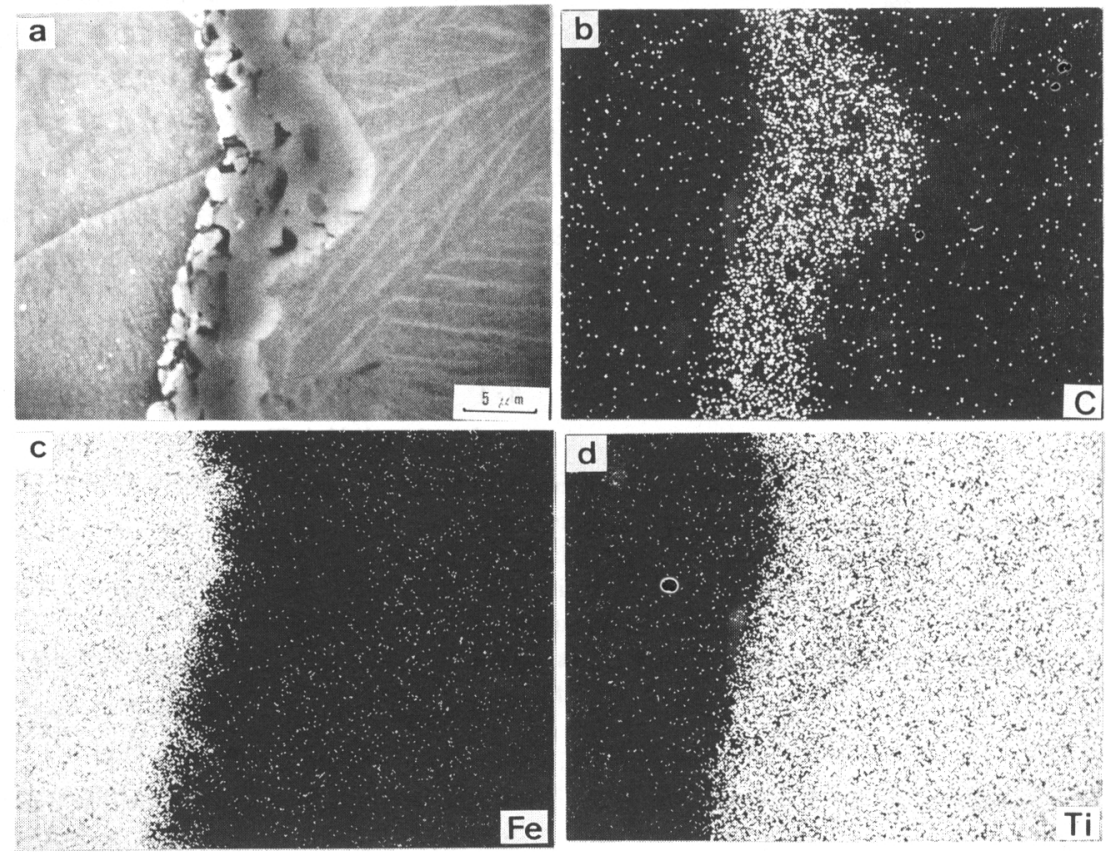

Photo. 1. TiC observed along the carbon steel/Ti interface heated at $1123 \mathrm{~K}$ for $921.6 \mathrm{ks}$ (a) Distribution of each element is shown in (b), (c) and (d).

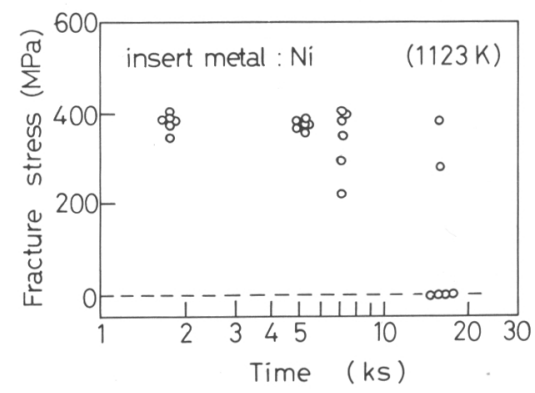

Fig. 3. Effect of holding time at $1123 \mathrm{~K}$ before rolling on fracture stress of carbon steel/Ti joint with the insert metal of $\mathrm{Ni}$.

イドが存在した。 $\mathrm{Ni}$ は fecであり, $\mathrm{Ti}$ 中へ少量侵入 すると bcc の $\beta$ - Ti を生成するため, $\mathrm{Ni}$ が $\mathrm{Ti}$ 中へ多量 に拡散するのに対し, Ti は $\mathrm{Ni}$ 中へはほとんど侵入し ない。そのため,ここで観察されたボイドはカーケンダ ル効果により生成したものと考えられる.

また，金属間化合物の部分の $\mathrm{Ti}, \mathrm{Ni}$ の分布を EPMA で測定した結果を Fig. 4 に示す. その組成は二元状態 図 ${ }^{5)}$ に示される $\mathrm{Ni}_{3} \mathrm{Ti}, \mathrm{NiTi}$ および $\mathrm{NiTi}_{2}$ にほぼ一致し た.すなわち,これらの金属間化合物は化学量論的化合

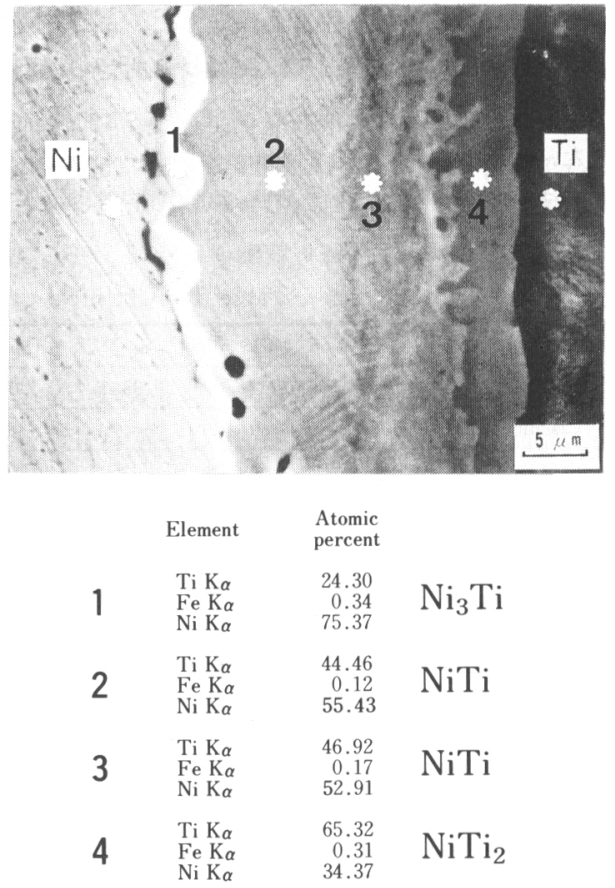

Photo. 2. EPMA point analysis from the intermetallic compound layer observed in the specimen of $\mathrm{Ni} / \mathrm{Ti}$ joint bonded at $1123 \mathrm{~K}$ for $57.6 \mathrm{ks}$. 


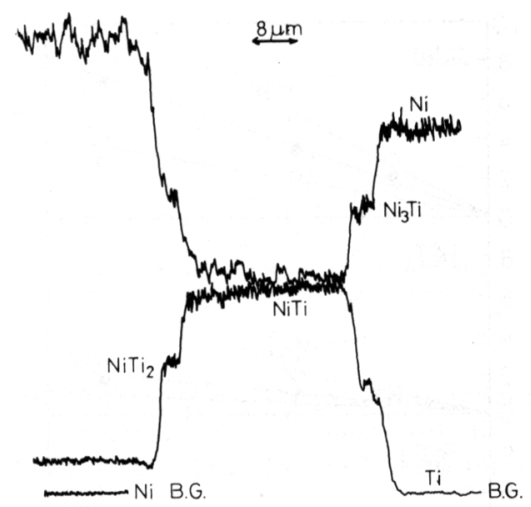

Fig. 4. EPMA line-scanning profiles across the bonding interface of $\mathrm{Ni} / \mathrm{Ti}$ joint bonded at $1123 \mathrm{~K}$ for $57.6 \mathrm{ks}$.

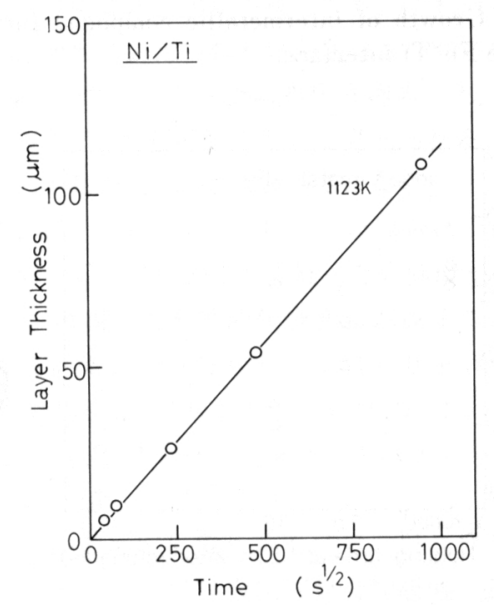

Fig. 5. Growth of intermetallic compound layer formed along the $\mathrm{Ni} / \mathrm{Ti}$ interface.

\section{物層である。}

接合材において観察された金属間化合物層幅を保持時 間の $1 / 2$ 乗に対して整理して Fig. 5 に示す. 化合物層 は時間の $1 / 2$ 乗に従つて成長しており，拡散律速であ ることがわかる.さらに，それぞれの化合物相に分けて， 成長過程を調査した結果を Fig. 6 に示す.いずれも時 間の $1 / 2$ 乗に従つて成長するが, 三種類の化合物相の うち, NiTi が他の相に比べて速く成長した.

圧延材の引張試験破面（Ni 側）を EPMAにて分析す ると, Photo. 3 に示すように, 大部分が $\mathrm{Ni}$ および $\mathrm{Ni}_{3} \mathrm{Ti}$ であつた。すなわち, 破断は $\mathrm{Ni} / \mathrm{Ni}_{3} \mathrm{Ti}$ 界面およ び $\mathrm{Ni}_{3} \mathrm{Ti}$ 相中で生じているものと考えられる.

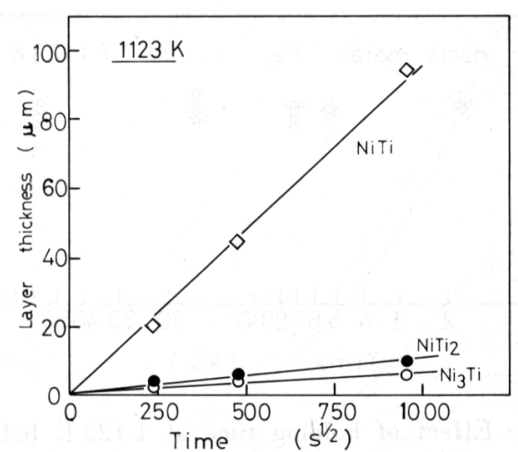

Fig. 6. Layer growth of intermetallic compound along the $\mathrm{Ni} / \mathrm{Ti}$ interface.
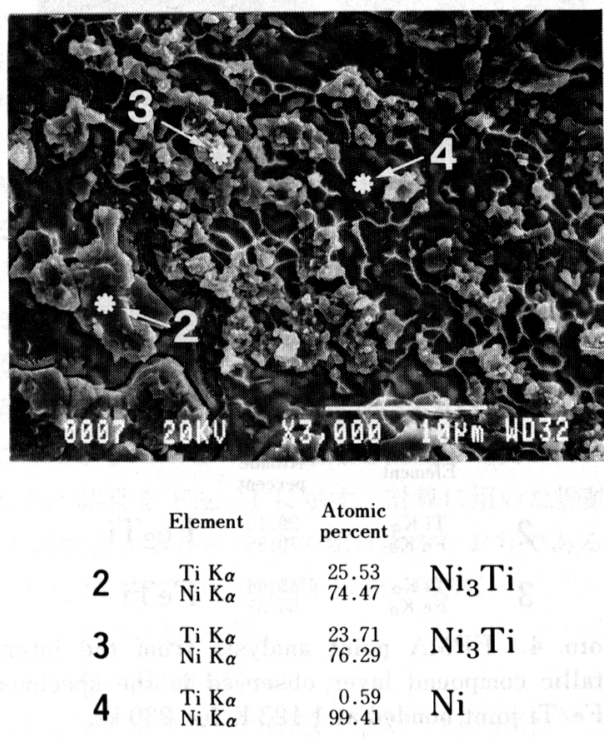

Photo. 3. EPMA point analysis from the fracture surface of carbon steel/Ti joint with the insert metal of $\mathrm{Ni}$ rolled at $1123 \mathrm{~K}$.

\section{$3 \cdot 3 \quad \mathrm{Fe}$ をインサート金属とする場合の接合性}

Fig. 7 に純鉄 $(\mathrm{Fe})$ をインサート材とした圧延材 (1 $123 \mathrm{~K}$ 加熱) の接合強度を示す. Fe インサート材は $\mathrm{Ni}$ インサート材に比べ, 長時間保持しても安定して高 強度を示す。

$1123 \mathrm{~K}$ での接合材 $\left(2.3 \times 10^{5} \mathrm{~s}\right.$ 保持 $)$ の $\mathrm{Ti} / \mathrm{Fe}$ 界面 の SEM 像を Photo. 4 に示す. 界面には二層の金属間 化合物が観察された. また， Ni の場合に観察されたボ イドは認められなかつた。さらに界面近傍における $\mathrm{Ti}$, $\mathrm{Fe}$ の分布を EPMA で観察した結果, $\mathrm{Ti}$ 中への $\mathrm{Fe}$ の 


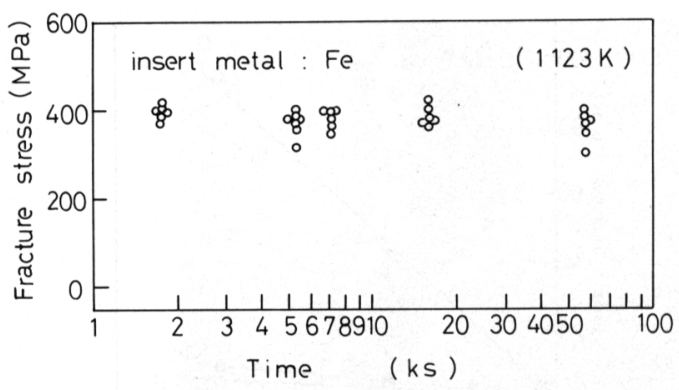

Fig. 7. Effect of holding time at $1123 \mathrm{~K}$ before rolling on fracture stress of carbon steel/ $\mathrm{Ti}$ joint with the insert metal of pure iron.

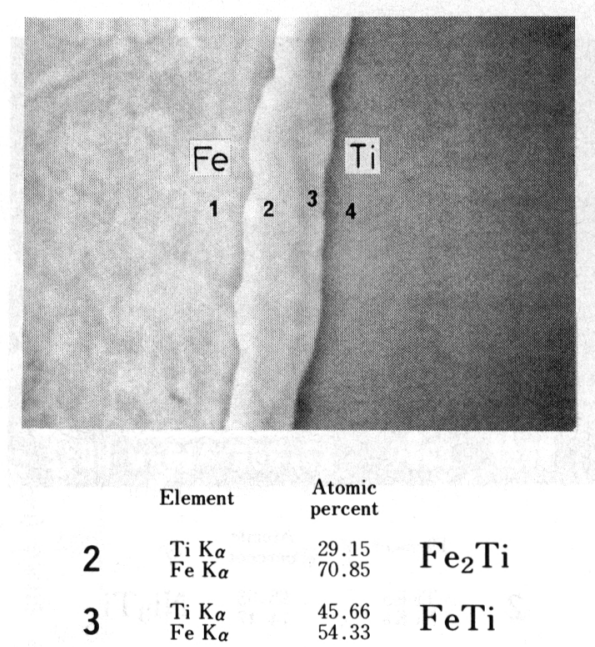

Photo. 4. EPMA point analysis from the intermetallic compound layer observed in the specimen of $\mathrm{Fe} / \mathrm{Ti}$ joint bonded at $1123 \mathrm{~K}$ for $230 \mathrm{ks}$.

拡散より $\mathrm{Fe}$ 中への $\mathrm{Ti}$ の拡散の方が，わずかながら大 きいことがわかつた。この温度では基本的には $\alpha-\mathrm{Fe}$ (bcc 構造) と $\alpha-\mathrm{Ti}$ (hcp 構造) の接合であるため, Fe 中への Ti の拡散の方が生じやすいためと考えられる.

金属間化合物層の EPMA 分析の結果, 二つの層は $\mathrm{Fe}_{2} \mathrm{Ti}$ と $\mathrm{FeTi}$ と同定された，接合材における金属間化 合物層幅と保持時間の $1 / 2$ 乗との関係を Fig. 8 に示す. ここでも，化合物層は時間の $1 / 2$ 乗に従つて成長して おり，拡散律速であることがわかる．しかし，金層間化 合物層幅は， Ni の場合に比べ著しく狭く，1123 K にて $2.3 \times 10^{5} \mathrm{~s}$ 保持しても, たかだか $3.5 \mu \mathrm{m}$ であつた。 こ れは $\mathrm{Ni}$ の場合の 1/10 以下である.これが Fe インサー ト材の安定した接合強度の理由であろう.

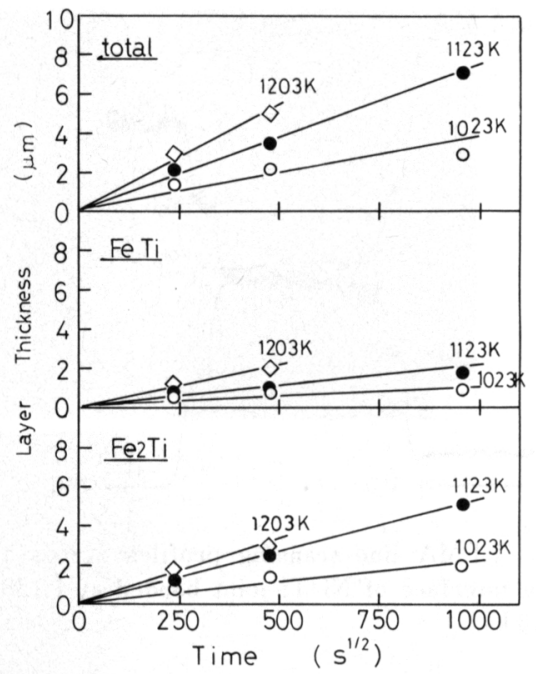

Fig. 8. Growth of intermetallic compound formed along the $\mathrm{Fe} / \mathrm{Ti}$ interface.

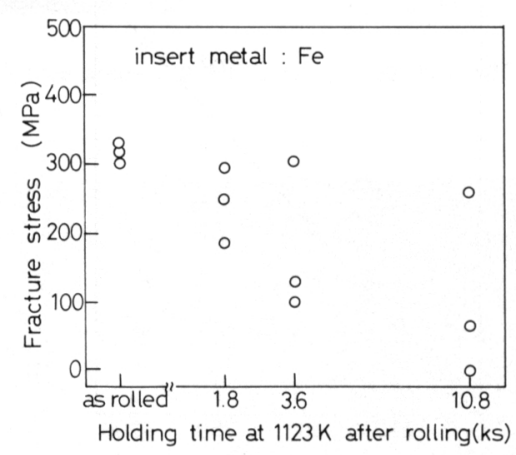

Fig. 9. Effect of holding time at $1123 \mathrm{~K}$ after rolling on the fracture stress of carbon steel/Ti joint with the insert metal of pure iron.

しかし，熱間加工等を想定して，圧延材を $1123 \mathrm{~K} に$ 再び加熱すると Fig. 9 に示すように，長時間加熱材の 接合強度は低下した。このとき，破面上には $\mathrm{TiC}$ と $\mathrm{Fe}_{2} \mathrm{Ti}, \mathrm{FeTi}$ が観察された (Fig. 10).

\section{4. 考察}

鉄鋼と $\mathrm{Ti}$ とを直接接合した場合, その接合強度に大 きなばらつきが認められることが知られている ${ }^{6) ~ 9) . こ ~}$ こでも, 安定した強度は得られなかつた。このため適正 なインサート材が必要となる。しかし，炭素（C）の拡 散を抑えるのに有効である $\mathrm{Ni}$ 箔をインサート材として 用いた場合, $\mathrm{Ni}$ が $\mathrm{Ti}$ 中へ侵入するとそれを $\beta$ 化し, 


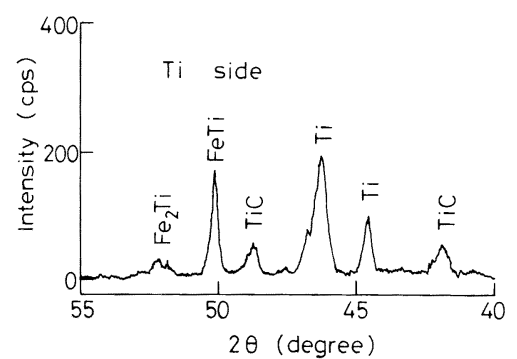

Fig. 10. X-ray diffraction pattern from fractured surface of carbon steel/ $\mathrm{Ti}$ joint with the insert metal of pure iron heated up to $1123 \mathrm{~K}$ for $10.8 \mathrm{ks}$ after rolling.

$\mathrm{fcc}$ 構造の $\mathrm{Ni}$ が bcc 構造の $\beta$ - Ti 中へ一方的に拡散し ていく結果, 厚い金層間化合物層と, その $\mathrm{Ni}$ 側にカー ケンダル効果によると考えられるボイドを生成すること になる，金属間化合物を生成しても，それ自身が延性に 富み塑性変形に耐えられれば問題はないわけであるが， $\mathrm{Ni}$ と $\mathrm{Ti}$ の間に生じる金属間化合物のうち $\mathrm{Ni}_{3} \mathrm{Ti}$ は高 温でも硬く ${ }^{10)}$, 変形能が小さいと考えられる.このため, インサート材として Ni は適当ではない.

一方，Feをインサート材とした場合は，長時間加熱 して熱間圧延しても安定して高い接合強度が得られた。 $\mathrm{Fe}$ と $\mathrm{Ti}$ の間にも金属間化合物は形成するが，化合物 層は著しく薄く，1 $123 \mathrm{~K}$ にて $2.3 \times 10^{5} \mathrm{~s}$ 保持しても， たかだか $3.5 \mu \mathrm{m}$ であつた。これは $\mathrm{Ni}$ インサートの場 合の $1 / 10$ 以下であり，インサート材としては Feの方 が優れている.

$\mathrm{Fe}-\mathrm{Ti}$ 系の反応拡散に関しては，既に研究されてい $3^{11) \sim 13)}$ が，ここでは金属間化合物層幅 $(d)$ が拡散時 間 $(t)$ の $1 / 2$ 乗則に従うことがわかつたので,これら の層成長速度定数 $(k)$ を計算した $(d=k \sqrt{t})$. 速度定 数の 2 乗の温度依存性は次のように示される。

$$
k^{2}=1.3 \times 10^{-111} \exp \left(-116 \mathrm{~kJ} \cdot \mathrm{mol}^{-1} / R T\right)
$$

日野谷ら ${ }^{14)}$ が測定した $\mathrm{Ni} / \mathrm{Ti}$ 界面での金属間化合物層 成長の活性化エネルギーは $19 \mathrm{~kJ} \cdot \mathrm{mol}^{-1}$ であり，上記 $\mathrm{Fe} / \mathrm{Ti}$ 界面での層成長の活性化エネルギーに比べ著し 〈小さく, Ni の方が金層間化合物層の成長速度が大き いことと一致する.

いずれにしても，Ti を合せ材としたクラッド鋼を考 えた場合，インサート材として純鉄を選ぶことにより， 熱間压延法による Ti クラッド鋼の製造が可能である. しかし，製造された Ti クラッド鋼を加工・使用するこ とを想定し，長時間再加熱すると接合強度は低下した (Fig. 9)。このとき，界面には Fe-Ti の金属間化合物

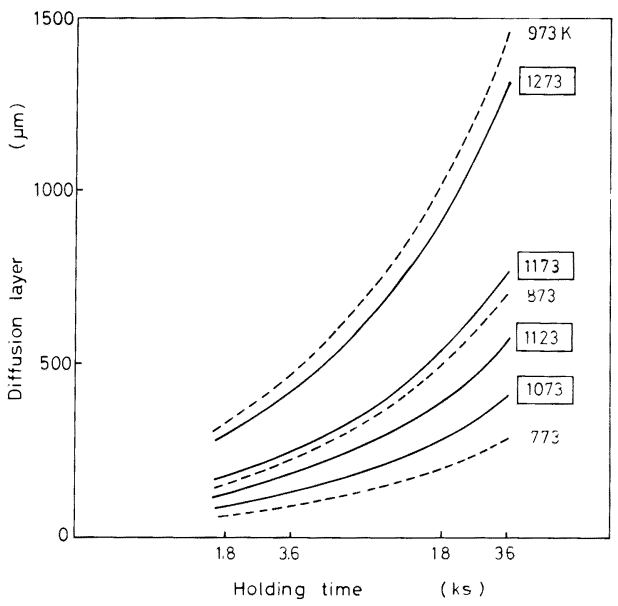

Fig. 11. Diffusion of carbon atom in Fe. Solid line shows the diffusion in austenite and dotted line in ferrite phase.

のみならず, $\mathrm{TiC} も$ 観察され (Fig. 10), これらが混在 することにより接合強度が低下するという桃野らの結 果 ${ }^{13)}$ とも一致する.この場合, インサート材には炭素 がほとんど含まれていないため，ここで観察された炭素 は母材炭素鋼中に存在したものが, 純鉄インサート材を 通過して $\mathrm{Fe} / \mathrm{Ti}$ 界面まで拡散したものと考えられる。 そこで $\mathrm{Fe}$ 中での C の拡散距離を温度と時間の関数で計 算した．結果をFig. 11 に示す. 計算に用いた振動因子 $D_{0}$ と活性化エネルギー $Q$ の值は次のとおりである ${ }^{16)}$.

i ） $\alpha-\mathrm{Fe}$ 中での C の拡散 $(773 \sim 973 \mathrm{~K})$

$$
\begin{aligned}
& D_{0}=0.20 \mathrm{~cm}^{2} / \mathrm{s} \\
& Q=102.8 \mathrm{~kJ} / \mathrm{mol}
\end{aligned}
$$

ii ) $\gamma$-Fe 中でのCの拡散 $(1073 \sim 1673 \mathrm{~K})$

$$
\begin{aligned}
& D_{0}=0.15 \mathrm{~cm}^{2} / \mathrm{s} \\
& Q=133.8 \mathrm{~kJ} / \mathrm{mol}
\end{aligned}
$$

例えば, 元の純鉄インサート材厚さが $1 \mathrm{~mm}$ であつても, 圧下比 5 にて熱間压延すると, 圧延後にはインサート材 厚さが $200 \mu \mathrm{m}$ となり, その後 $873 \mathrm{~K} に 3.6 \mathrm{ks}$ 加熱す ると, Cの拡散距離は $220 \mu \mathrm{m}$ にも達する. すなわち, インサート材の厚さが薄く, 長時間高温加熱される場合 には，母材炭素鋼中のCが Feインサートを通過して， $\mathrm{Fe} / \mathrm{Ti}$ 界面で $\mathrm{TiC}$ となることは十分可能である. そこ で，母材炭素鋼からのC拡散を防ぐため, Feインサー トの母材炭素鋼側に $\mathrm{Ni}$ 箔を挿入して，炭素鋼/ $\mathrm{Ni} / \mathrm{Fe} / \mathrm{Ti}$ の組合せにて熱間圧延を行つた。 $\mathrm{Ni}$ 箔の厚さ を $300 \mu \mathrm{m}$ とし， Feインサート厚さを変化させ $1123 \mathrm{~K}$ にて熱間圧延後， $873 \mathrm{~K}$ に再加熱した。 $3.6 \mathrm{ks}$ 再加熱後 


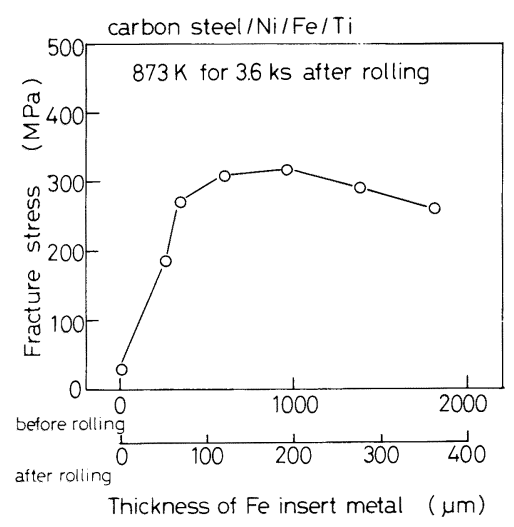

Fig. 12. Fracture stress of carbon steel/Ti joint with the insert metal of both $\mathrm{Ni}$ and $\mathrm{Fe}$ heated up to $873 \mathrm{~K}$ for $3.6 \mathrm{ks}$ after rolling at $1123 \mathrm{~K}$.

の接合強さを Fig. 12 に示す. Fe インサート材の厚さ が $400 \mu \mathrm{m}$ 以上であれば, 圧延後 $\mathrm{Ni}$ インサートが 60 $\mu \mathrm{m}, \mathrm{Fe}$ インサート材が $80 \mu \mathrm{m}$ 以上となり,この後 873 $\mathrm{K}$ で $3.6 \mathrm{ks}$ 加熱しても, 安定した接合強さが得られる ことが明らかとなつた。

\section{5. 結言}

接合界面の元素拡散挙動と金属間化合物層の生成に着 目して, Ti と鉄鋼の接合性を検討し，次のような結論 が得られた。

(1)インサート材を用いないで $\mathrm{Ti}$ と炭素鋼を直接接 合すると, 接合界面に $\mathrm{TiC}$ が生成し, 安定して高い接 合強さが得られない.

( 2 ) Ni をインサート材として Ti と鉄鋼を接合する と, $\mathrm{Ni}$ と $\mathrm{Ti}$ の界面には $\mathrm{Ni}_{3} \mathrm{Ti}, \mathrm{NiTi}$ および $\mathrm{NiTi}_{2}$ が生 成し，それらの Ni 側にはカーケンダル効果によると考 えられるボイドが存在した．このとき，金属間化合物相 の層成長は拡散時間の $1 / 2$ 乗に従つており, 長時間保
持すると化合物層が大きくなり, 高い接合強度が得られ ない.

( 3 ) Fe をインサート材として $\mathrm{Ti}$ と炭素鋼を接合し た場合にも，その界面に $\mathrm{Fe}_{2} \mathrm{Ti}$ および $\mathrm{FeTi}$ が生成す るが，これら化合物相の層成長速度は $\mathrm{Ni}$ インサート材 の場合に比べ著しく小さい，そのため，Feをインサー ト材とした場合には安定して高い接合強度が得られる.

（4）しかし，Feをインサート材として熱間圧延され た Ti クラッド鋼を長時間再加熱すると，接合強度は低 下寸る．これは，母材炭素鋼中の Cが Fe インサート材 を通過して拡散し， $\mathrm{Fe} / \mathrm{Ti}$ 界面で $\mathrm{TiC}$ をも形成するた めと考えられる。

(5)そのため, Feインサート材の母材炭素鋼側に Ni 箔を挿入した炭素鋼 $/ \mathrm{Ni} / \mathrm{Fe} / \mathrm{Ti}$ の組合せが有効である.

\section{文献}

1) 庭月野享, 氏元泰弘: 圧力技術，24（1983)，p. 179

2 ) A. H. Holtzman and C. G. Rudershausen: Sheet Metal Industries, 39 (1962), p. 399

3) J. L. MA and C. Wright, Jr.: Met. Progress, 77 (1960), p. 76

4 ）小山吉郎，遠藤良幸，相沢 実，鈴木 建: 日本製鋼技報, 16 (1964), p. 54

5 ) M. HANSEN: Constitution of Binary alloy (1958) [McGraw-Hill]

6 ）島崎正英, 加賀 寿, 馬場幸彦, 中島 進, 前田英二: 鉄と鋼, 71 (1985), S 1645

7 ) Y. Arata, $K$. Terai, S. Matsuda, $H$. Nagai and $T$. YAMADA: Trans. JWS, 4 (1973), p. 96

8 ) 吉原征四郎, 川並高雄, 鈴木堅市: 鉄と鋼, 72 (1986), p. 671

9 ) G. K. Kharchenko: Auto. Weld., 22 (1969), p. 31

10) W. J. BUEHLER and R. C. WILEY: Trans. ASM, 55 (1962), p. 269

11）平野賢一, 一法師康武: 日本金属学会誌, 32 (1968), p. 815

12) 辻 新次: 日本金属学会誌, 40 (1976), p. 844

13）南埜宜俊, 山根寿己, 大西宏和, 高橋知司: 高温学会誌, 12 (1986), p. 189

14）日野谷重晴, 大森靖也: 溶接学会界面接合委員会資料, IJ-34-87 (1987)

15）桃野 正，圓城敏男，池内建二: 鉄と鋼，73（1987）, p. 1590

16）金属データブック（日本金属学会編）（1974） 